\title{
Urogenital Mycoplasmosis and Pregnancy
}

\section{Põder $\mathbf{A}^{*}$ and Haldre $\mathbf{M}$}

Tartu Univerisity Clinics Foundation, Clinical Research Center, Estonia Tartu Sõbra-54, Estonia

*Corresponding author: Airi Põder, Tartu Univerisity Clinics Foundation, Clinical Research Center, 51013, Estonia Tartu Sõbra 54, Estonia, Tel: 3725058949; E-mail: Airi.Poder@std.ee

\section{Received date: November 11, 2016; Accepted date: December 6, 2016; Published date: December 14, 2016}

Copyright: (C) 2016 Poder A, et al. This is an open-access article distributed under the terms of the Creative Commons Attribution License, which permits unrestricted use, distribution, and reproduction in any medium, provided the original author and source are credited.

\begin{abstract}
Urogenital mycoplasmas Ureaplasma urealyticum, Ureaplasma parvum and Mycoplasma hominis have long been considered commensals of human urogenital microflora. Several studies have recently clarified whether these bacteria could cause or be associated with various obstetric complications. Epidemiologic studies have found high prevalence of Ureaplasma spp. and M. hominis among otherwise healthy population. On the other hand, $U$. urealyticum, $U$. parvum and $M$. hominis have increasingly been linked to adverse pregnancy outcomes such as spontaneous pre-term labor, pre-term premature rupture of fetal membranes, miscarriage, stillbirth and low birth weight. However, no convincing causal relationship has been shown. Studies have shown that antibiotics resistance is on the rise and differs considerably by regions. Screening of asymptomatic patients for $M$. hominis, U. urealyticum and $U$. parvum is currently still not indicated.
\end{abstract}

Keywords: Mycoplasmas; Pregnancy; M. hominis, Ureaplasmas

\section{Introduction}

The name mycoplasma has been used as the general name for the class Mollicutes the smallest free-living microorganisms. In the urogenital tract, the relevant Mollicutes are Mycoplasma genitalium and Mycoplasma hominis and two species of ureaplasmas-Ureaplasma urealyticum and Ureaplasma parvum. This article aims to give a short overview of associations and causative roles of aforementioned mycoplasmas with various obstetric complications. Brief summary is provided about recent trends in treatment.

\section{Epidemiology}

Ureaplasmas and $M$. hominis are considered opportunistic pathogens because they can be isolated from the lower urogenital tract of healthy women as well as from individuals with disease. Table 1 summarizes the prevalence of urogenital mycoplasmas as found by different researchers.
As can be seen from Table 1, then prevalence varies considerably from study to study [1-5]. Prevalence of $M$. genitalium has been found to be between $0.3-1.2 \%[6,7]$.

That is lower than the prevalence of Chlamydia trachomatis but higher than that of Neisseria gonorrhoeae. A few researches have differentiated between $U$. urealyticum and $U$. parvum. In these studies U. parvum makes up around $80 \%$ of total detected Ureaplasma spp. Some studies have found $M$. hominis only as co-infection with ureaplasmas $[6,8,9]$.

\section{Role in obstetric complications}

Ureaplasmas and $M$. hominis are considered commensals of human microflora, although increasing amount of research finds associations between adverse outcomes of pregnancy and colonisation of ureaplasmas and $M$. hominis. Nevertheless, there is still no definitive consensus on their causative role. Next, short summary of recent findings is provided.

\begin{tabular}{|c|c|c|c|c|c|c|}
\hline Study & Ureaplasma spp & U. parvum & M. hominis & M. Genitalium & Sample size & Population \\
\hline Pignanelli et al. & - & - & $3.30 \%$ & - & 2,480 & $\begin{array}{l}\text { Symptomatic patients in } \\
\text { Italy }\end{array}$ \\
\hline Verteramo et al. & $28 \%$ & - & $5 \%$ & - & 3,155 & $\begin{array}{l}\text { Non-pregnant } \\
\text { aged 14-57, romen } \\
\text { gynaecological care, in } \\
\text { Italy }\end{array}$ \\
\hline Pónyai et al. & $12 \%$ & - & $1.3 \%$ & - & 2,309 & $\begin{array}{l}\text { Sexually active women in } \\
\text { Hungary }\end{array}$ \\
\hline De Francesco et al. & $18 \%$ & - & $2 \%$ & - & 9,956 & $\begin{array}{lr}\text { Outpatients, } & \text { routine } \\
\text { check, } & \text { pregnancy } \\
\text { screenings etc, Italy }\end{array}$ \\
\hline
\end{tabular}


Page 2 of 6

\begin{tabular}{|c|c|c|c|c|c|c|}
\hline $\begin{array}{l}\text { Ouzounova-Raykova } \\
\text { et al. }\end{array}$ & $15 \%$ & - & $3 \%$ & $0.3 \%$ & 348 & Women in Bulgaria \\
\hline Tibaldi et al. & $17 \%$ & - & $2 \%$ & - & 27,000 & Non-pregnant women \\
\hline $\begin{array}{l}\text { Zdrodowska-Stefanow } \\
\text { et al. }\end{array}$ & $23 \%$ & - & $4 \%$ & - & 541 & $\begin{array}{l}\text { Women aged 18-55, } \\
\text { gynaecological and STD } \\
\text { outpatient clinics }\end{array}$ \\
\hline Naaber et al. & $7.7 \% \mathrm{Uu}^{*}$ & $32 \%$ & $8 \%$ & $1.2 \%$ & 4,985 & $\begin{array}{l}85 \% \text { women, } 15 \% \text { men, } \\
\text { Estonian STD clinics } \\
\text { patients }\end{array}$ \\
\hline Ye et al. & $53 \%$ & - & $12 \%$ & - & 37,055 & Women in Hangzhou \\
\hline Redelinghuys et al. & $76 \%$ & - & $40 \%$ & - & 96 & $\begin{array}{l}\text { Pregnant South-African } \\
\text { women }\end{array}$ \\
\hline Kataoka et al. & $8.7 \% \mathrm{Uu}^{*}$ & $52 \%$ & $11 \%$ & $0.8 \%$ & 877 & Pregnant women \\
\hline
\end{tabular}

Table 1: Prevalence of urogenital mycoplasmas.

\section{Ureaplasma spp.}

Ureaplasma genital tract colonization has been associated with adverse pregnancy outcomes such as spontaneous abortion [10], premature rupture of membranes (PROM) [4], premature delivery
[11], neonatal morbidity and perinatal death [12]. The methodology and samples vary considerably between studies, which makes combining and synthesizing the result difficult. Therefore, the results are presented as stated by studies in a Table 2 .

\begin{tabular}{|c|c|c|c|}
\hline Study & Sample size & Population & Result \\
\hline \multirow[t]{2}{*}{ Witt et al. } & 132 & $\begin{array}{l}\text { Patients with preterm labor or PROM, sample from } \\
\text { amniotic cavity }\end{array}$ & \multirow{2}{*}{$\begin{array}{l}\text { Statistically significant association betweer } \\
\text { intrauterine colonization with } U \text {. urealyticum anc } \\
\text { both therapy-resistant preterm labor anc } \\
\text { preterm premature rupture of membranes } \\
(\text { PPROM }(p<0.001)\end{array}$} \\
\hline & 75 & Control group, other indication for cesarean section & \\
\hline \multirow[t]{2}{*}{ Kacerovský et al. } & 225 & Patients with PROM, 24 to 36 weeks of gestation & \multirow{2}{*}{$\begin{array}{l}\text { Statistically significant difference between } \\
\text { groups with PPROM and control group } \\
(p<0.0001) \text {. }\end{array}$} \\
\hline & 225 & Pregnant control group & \\
\hline \multirow[t]{2}{*}{ Ahmadi et al. } & 109 & Spontaneous abortion, 10 to 20 weeks of gestation & \multirow{2}{*}{$\begin{array}{l}\text { Statistically significant association between } U \text {. } \\
\text { urealyticum endocervical infection and } \\
\text { spontaneous abortion at gestation age between } \\
10-20 \text { weeks }\end{array}$} \\
\hline & 109 & Pregnant control group & \\
\hline \multirow[t]{2}{*}{ Abele-Horn et al. } & 172 & U. urealyticum positive pregnant women & \multirow{2}{*}{$\begin{array}{l}\text { Statistically significant association between } \\
\text { vaginal colonisation with } U \text {. Urealyticum and } \\
\text { decrease of birth weight }(p<0.0001) \text {, gestational } \\
\text { age }(p<0.0001) \text {, increase of chorioamnionitis } \\
(p<0.0001) \text { and preterm delivery }(p<0.001) \text {. Low } \\
\text { colonization levels had no effect on an adverse } \\
\text { outcome of pregnancy }\end{array}$} \\
\hline & 123 & $U$. urealyticum negative pregnant women & \\
\hline \multirow[t]{2}{*}{ Mitsunari et al. } & 23 & Patients with preterm labor & \multirow{2}{*}{$\begin{array}{l}\text { Statistically significant association between } \\
\text { cervical } U \text {. Urealyticum colonization and preterm } \\
\text { delivery }(p=0.0111)\end{array}$} \\
\hline & 59 & Pregnant control group & \\
\hline \multirow[t]{2}{*}{ Kataoka et al. } & 21 & Patients with preterm labor or abortion & \multirow{2}{*}{$\begin{array}{l}\text { Vaginal colonization with } U \text {. parvum, but not } U \text {. } \\
\text { urealyticum, is associated with late abortion or } \\
\text { early preterm birth }\end{array}$} \\
\hline & 856 & Pregnant control group & \\
\hline
\end{tabular}

Table 2: Results of studies on association of ureaplasmas with obstetric complications.

Witt et al. [13] found that the amniotic cavity of $44 \%$ of patients with PROM and therapy-resistant preterm labor was colonized with $U$. urealyticum compared to only $2.7 \%$ in control group of pregnant women. Mitsunari et al. [11] findings support the association between cervical $U$. urealyticum and preterm delivery (controls colonisation $46 \%$ compared to $87 \%$ in preterm delivery patients).

Very few studies distinguish between $U$. urealyticum and $U$. parvum and describe the influence of Ureaplasma spp. combined. Even if an 
Page 3 of 6

article states that $U$. ureaplasma is studied, then careful examination of methods section reveals that the method used does not allow to differentiate between biovars. Nevertheless, some researchers have made the distinction. Kataoka et al. [14] found that $U$. parvum but not $U$. urealyticum is associated with late abortion or early preterm birth. Kasprzykowska et al. [15] found that colonization of the lower urogenital tract with $U$. parvum can cause asymptomatic infection of the upper reproductive system. Kasper et al. [16] found that the increased amount of $U$. parvum was significantly linked to histological chorioamnionitis, PROM together with preterm labor, early-onset sepsis, and bronchopulmonary dysplasia. Furthermore, no significant difference between the bacterial load of $U$. urealyticum and neonatal outcome was observed [16]. The importance of bacterial load was found by Abele-Horn et al. [17]. The study revealed that high colonization $\left(>10^{5} \mathrm{cfu} / \mathrm{ml}\right)$ level with $U$. urealyticum was associated with a significant increase of clinical chorioamnionitis, PROM and preterm delivery. Low density vaginal colonization levels had no effect on clinical chorioamnionitis and preterm delivery [17].

Greenow et al. [18] studied whether treatment of pregnant women heavily colonized with ureaplasma with erythromycin could have an impact on birth weight, but found no statistically significant difference [18]. However, in this study the antibiotics treatment was started only between $22-32^{\text {th }}$ week of gestation, whereas obstetric adverse outcomes, such as abortion may arise much earlier.

\section{M. hominis}

Evidence has accumulated that $M$. hominis may be of significance in the condition of bacterial vaginosis. Bacterial vaginosis (BV) in turn has been associated with subsequent early pregnancy loss [19]. Donders et al. [19] studied BV and found that M. hominis, and $U$. urealyticum were associated with an increased risk of early miscarriage. $M$. hominis may act symbiotically with other BVassociated bacteria or as the sole pathogen based on the observation that this mycoplasma can be found in large numbers in the vagina of most women with BV, but less often in healthy women [20].

\section{M. genitalium}

Mycoplasma genitalium is a globally important sexually transmitted pathogen known to cause urethritis [21]. However, there is no conclusive evidence supporting its role in adverse obstetric outcomes and tubal infertility. Data suggests an association between cervicitis and $M$. genitalium. Supporting evidence of causal relationship between pelvic inflammatory disease and $M$. genitalium is moderate to strong [21].

Existing data provide some support for the hypothesis that $M$. genitalium can cause female infertility, but are inconclusive [22]. A few studies have found an independent association between vaginal presence of $M$. genitalium and preterm delivery [23,24]. However, causative association of $M$. genitalium with adverse obstetric outcomes remains unestablished [25].

\section{Diagnostics}

Ureaplasmas and $M$. hominis are considered to be a part of natural microflora among healthy women and men. Consequently, the detection of these bacteria has a low positive predictive value in relation to diseases. Therefore, currently, most reviews do not recommend the inclusion of these pathogens into the routine sexually transmitted infections (STI) screening protocols and state that asymptomatic individuals should not be screened with culture or nucleic acid amplification tests (NAAT).

As previously discussed, detection of $M$. genitalium is strongly correlated to diseases. As it is detected only rarely in healthy individuals, the positive predictive value of the test for M. genitalium is high. It has been suggested that $M$. genitalium could be among routinely screened microbes as are C. trachomatis and $N$. gonorrhoeae.

\section{Laboratory Methods}

\section{Culture and microscopy}

Culture has been previously considered the gold standard in the detection of ureaplasmas but it is a difficult method since these fastidious organisms require the presence of serum, metabolic substrate and growth factors [26]. In addition, some commercial kits available for diagnosis of urogenital mollicute infections have demonstrated lack of diagnostic sensitivity [27]. Lack of a rigid cell wall makes it nearly impossible to directly visualize ureaplasma by light microscopy. The laboratory testing of $M$. genitalium has been particularly difficult as it takes several weeks or even months for each isolate to grow, making culture impossible to use for diagnostics in routine clinical practice [28].

Therefore, owing to the poor and extremely slow growth of the bacterium in culture, diagnosis of $M$. genitalium infection is performed exclusively using nucleic acid amplification tests (NAAT) [28].

\section{Polymerase chain reaction (PCR)}

PCR has been introduced in the practice because of the possibility to use different clinical materials, quick test results and possibility to detect different pathogens in a swab [7]. PCR is also more sensitive than culture for detection ( $<100$ genome copies) of nonviable as well as viable ureaplasmas. The results of PCR are available in a day, whereas a culture takes 2-5 days. The most commonly used gel-based traditional and real-time PCR protocols target the common multiple-banded antigen (mba), urease or 16s RNA genes. Currently new sensitive and low-cost multiplex PCR methods are being developed to make diagnosis by nucleic acid amplification tests (NAATs) more costefficient [29].

However, at the moment there is no gold standard PCR test which to compare other new tests with. When choosing the PCR test for use, it must be accounted for that PCR of some MgPa-related sequences may fail to detect some strains of $M$. genitalium due to antigenic variability $[25,28]$.

\section{Quantitative-PCR (qPCR)}

Conventional PCR is restricted in the accurate quantification of microorganisms. In contrast, quantitative real-time PCR (qPCR) using fluorescence dyes or probes facilitate the quantification of amplified viral, bacterial, and parasitic products. As it was previously discussed, in some obstetric complications the amount of bacteria is more important than the mere presence of it [16].

PCR is an excellent alternative to culture, but culture allows antibiotic susceptibility testing. However, molecular testing for macrolide and fluoroquinolone resistance mediating mutations is also possible. 
Page 4 of 6

\section{Specimen collection}

There is still no consensus as to which specimens have the best sensitivity in detection of ureaplasmas and $M$. genitalium. For $M$. genitalium the use of more than one specimen may significantly improve the diagnostic sensitivity. Lillis et al. [30] found that the single best specimen for the detection of $M$. genitalium infection was vaginal swab specimen, followed in order of decreasing relative sensitivity by endocervical swab specimen $(74.3 \%)$, urine specimen $(61.4 \%)$, and rectal swab specimen $(24.3 \%)$.

Vaginal swab combined with endocervical swab provided a sensitivity of $95.7 \%$ [30]. Research has also shown that self-collected vaginal swabs are equal to clinician-collected vaginal swabs for diagnosis of C. trachomatis and $N$. gonorrhoeae, and there is no reason to doubt that the same would be true for M. genitalium [30].

\section{General Treatment}

Mycoplasmas and ureaplasmas lack a cell wall, the target of betalactam antibiotics and vancomycin, which makes them resistant to these antibiotics. Additionally, ureaplasma species have natural resistance to lincosamides (e.g. clindamycin) and $M$. hominis possesses inherent resistance to macrolides, except josamycin [31].
Historically, tetracyclines, macrolides, and quinolones have been the major antibiotics used in the treatment of urogenital infections caused by mycoplasmas. However, their therapeutic efficacy may be unpredictable due to increasing resistance. The extent of resistance varies regionally according to different antimicrobial therapy policies and the history of prior antimicrobial exposure in different populations. Recently, several articles have been published that study the resistance of $M$. hominis and ureaplasma to antibiotics. Table 3 summarizes the results of these studies. De Francesco et al. [32] studied a sample of 9,956 patients in Italy. Both $M$. hominis and Ureaplasma spp. (no differentiation was made between $U$. parvum and $U$. urealyticum) were most sensitive to doxycycline and tetracycline, as well as to josamycin.

Clarithromycin and josamycin were the most potent macrolides against ureaplasmas. The only macrolide effective against $M$. hominis was josamycin. Another antibiotic effective against both microbes was pristinamycin. Other two macrolides that were studied-azithromycin and erythromycin - were only moderately effective [32]. Resistance to erythromycin has been reported additionally by Ponyai et al. [31] and Krausse et al. [33] who determined that the resistance of ureaplasmas to erythromycin is $81 \%$ and $21 \%$, respectively.

\begin{tabular}{|c|c|c|c|c|c|c|c|c|c|}
\hline & \multicolumn{2}{|c|}{ Francesco et al. $(9,956)$} & \multicolumn{2}{|c|}{ Ponyai et al., $(2,309)$} & \multicolumn{2}{|c|}{ Krausse et al., (469) } & \multicolumn{2}{|c|}{ Ye et al. $(37,055)$} & \multirow{2}{*}{$\begin{array}{l}\text { Pignanelly et al. } \\
(2,480)\end{array}$} \\
\hline & Ureapl. & M. hominis & Ureapl. & M. hominis & Ureapl. & M. hominis & Ureapl. & M. hominis & \\
\hline Doxycycline & $2 \%$ & $1 \%$ & $2 \%$ & $2 \%$ & $1 \%$ & $10 \%$ & $2 \%$ & $0 \%$ & $4 \%$ \\
\hline Tetracycline & $2 \%$ & $1 \%$ & $4 \%$ & $12 \%$ & $3 \%$ & $11 \%$ & $3 \%$ & $2 \%$ & $7 \%$ \\
\hline Erythromycin & $10 \%$ & $99 \%$ & $81 \%$ & - & $21 \%$ & $96 \%$ & $1 \%$ & $98 \%$ & $85 \%$ \\
\hline Clarithromycin & $5 \%$ & $99 \%$ & - & - & $5 \%$ & $99 \%$ & $0 \%$ & $97 \%$ & $80 \%$ \\
\hline Josamycin & $1 \%$ & $1 \%$ & - & - & $2 \%$ & $3 \%$ & $0 \%$ & $0 \%$ & $1 \%$ \\
\hline Azithromycin & $5 \%$ & $99 \%$ & $10 \%$ & - & $7 \%$ & $99 \%$ & $0 \%$ & $67 \%$ & $75 \%$ \\
\hline Ciprofloxacin & $60 \%$ & $100 \%$ & - & - & $16 \%$ & $8 \%$ & $75 \%$ & $55 \%$ & $60 \%$ \\
\hline Ofloxacin & $5 \%$ & $100 \%$ & $25 \%$ & $5 \%$ & $2 \%$ & $2 \%$ & $53 \%$ & $55 \%$ & $22 \%$ \\
\hline Pristinamycin & $1 \%$ & $1 \%$ & - & - & - & - & $0 \%$ & $0 \%$ & $4 \%$ \\
\hline Clindamycin & - & - & $75 \%$ & $5 \%$ & $43 \%$ & $0 \%$ & - & - & - \\
\hline
\end{tabular}

Table 3: Percentage of resistant strains, sample size in brackets.

Pignanelly et al. [5] studied $M$. hominis and found that the isolates were sensitive to tetracycline and doxycycline but resistant to fluoroquinolones and macrolides except jocamycin. Krausse et al. [33] found that doxycycline was the most active tetracycline against ureaplasmas and $M$. hominis. However, $10-13 \%$ of $M$. hominis was resistant to tetracyclines [33].

Nevertheless, doxycycline is still the drug of choice for the treatment of urogenital mycoplasma infections and may also be used for coinfection with $M$. hominis [33]. However, resistant strains are increasingly prevalent. In accordance with current guidelines, the International Union against Sexually Transmitted Infections (IUSTI) recommends use of macrolides in case of uncomplicated M. genitalium in the absence of macrolide resistancy mediating mutations: azithromycin $500 \mathrm{mg}$ on day one, then $250 \mathrm{mg}$ once daily for days $2-5$ orally or josamycin $500 \mathrm{mg} 3$ times daily for 10 days.

If case of macrolide-resistancy, moxifloxacin $400 \mathrm{mg}$ once daily for 7-10 days may be considered as a treatment option, however it is contraindicated in pregnancy $[25,34]$. Josamycin has been shown to be in vitro effective against $M$. genitalium [35]. This 16-membered macrolide is widely used in Italy, Russia, France, Spain, etc.

In recently published study treatment with josamycin was associated with $93.5 \%$ eradication rate in male patients with $M$. genitalium infection with josamycin $500 \mathrm{mg}$ three times daily for 10 days [36]. In countries where josamycin is available, it could be considered for treatment in case of M. genitalium infection. 
Page 5 of 6

\section{Treatment during pregnancy}

During pregnancy, the list of antibiotics that are not contraindicated but effective against urogenital mycoplasmas is much shorter. Macrolides and clindamycin are allowed. Erythromycin, the antibiotic most commonly used for treating pregnant women, has shown only moderate activity. The only macrolide that has shown consistent effectiveness against both ureaplasmas and $M$. hominis is josamycin which is also allowed to be used during pregnancy $[27,32,37,38]$. The different configuration of the molecule of josamycin makes it resistant to efflux pump, an important mechanisms of resistance that bacteria may possess $[39,40]$. M. genitalium infections can be treated with azithromycin and josamycin, however, resistance may pose a problem.

\section{Conclusion}

$M$. hominis and U. urealyticum may be part of the normal vaginal flora but both are associated with obstetrics complications. The question of who should be screened for urogenital mycoplasmas and whether to treat the colonization to prevent obstetrics complications remains currently unsettled. $M$. genitalium is a definite urogenital pathogen and needs treatment. In accordance with current guidelines, josamycin and azithromycin are treatment of choice in case of the absence of macrolide resistance associated mutations in M.genitalium. Josamycin is safe to use in pregnancy in case there is a need to treat urogenital mycoplasmosis.

\section{References}

1. Tibaldi C, Cappello N, Latino MA, Masuelli G, Marini S, et al. (2009) Vaginal and endocervical microorganisms in symptomatic and asymptomatic non-pregnant females: risk factors and rates of occurrence. Clin Microbiol Infect 15: 670-679.

2. Verteramo R, Patella A, Calzolari E, Recine N, Marcone V, et al. (2013) An epidemiological survey of Mycoplasma hominis and Ureaplasma urealyticum in gynaecological outpatients, Rome, Italy. Epidemiol Infect 141: 2650-2657.

3. Zdrodowska-Stefanow B, Kłosowska WM, Ostaszewska-Puchalska I, Bułhak-Kozioł V, Kotowicz B (2006) Ureaplasma urealyticum and Mycoplasma hominis infection in women with urogenital diseases. Adv Med Sci 51: 250-253.

4. Kacerovský M, Pavlovský M, Tosner J (2009) Preterm premature rupture of the membranes and genital mycoplasmas. Acta Medica (Hradec Kralove) 52: 117-120.

5. Pignanelli S, Pulcrano G, Schiavone P, Iula VD, Catania MR (2015) In vitro antimicrobial susceptibility of Mycoplasma hominis genital isolates. Indian J Dermatol Venereol Leprol 81: 286-288.

6. Ouzounova-Raykova VV, Markovska R, Mizgova G, Mitov IG (2011) Detection of the sexually transmissible genital mycoplasmas by polymerase chain reaction in women. Sex Health 8: 445-446.

7. Naaber P, Ratnik K, Raud K, Sepp E, Poder A (2014) Relevance of molecular complex diagnostics for genital tract infections. Eesti Arst 93: 450-455.

8. Redelinghuys MJ, Ehlers MM, Dreyer AW, Lombaard HA, Kock MM (2014) Antimicrobial susceptibility patterns of Ureaplasma species and Mycoplasma hominis in pregnant women. BMC Infect Dis 14: 171.

9. Baka S, Kouskouni E, Antonopoulou S, Sioutis D, Papakonstantinou M, et al. (2009) Prevalence of Ureaplasma urealyticum and Mycoplasma hominis in Women With Chronic Urinary Symptoms. Urology 74: 62-66.

10. Ahmadi A, Khodabandehloo M, Ramazanzadeh R, Farhadifar F, Nikkhoo B, et al. (2014) Association between Ureaplasma urealyticum endocervical infection and spontaneous abortion. Iran J Microbiol 6: 392-397.
11. Mitsunari M, Yoshida S, Deura I, Horie S, Tsukihara S, et al. (2005) Cervical Ureaplasma urealyticum colonization might be associated with increased incidence of preterm delivery in pregnant women without prophlogistic microorganisms on routine examination. J Obstet Gynaecol Res 31: 16-21.

12. Bayraktar MR, Ozerol IH, Gucluer N, Celik O (2010) Prevalence and antibiotic susceptibility of Mycoplasma hominis and Ureaplasma urealyticum in pregnant women. Int J Infect Dis 14: 90-95.

13. Witt A, Berger A, Gruber CJ, Petricevic L, Apfalter P, et al. (2005) Increased intrauterine frequency of Ureaplasma urealyticum in women with preterm labor and preterm premature rupture of the membranes and subsequent cesarean delivery. Am J Obstet Gynecol 193:1663-1669.

14. Kataoka S, Yamada T, Chou K, Nishida R, Morikawa M, et al. (2006) Association between preterm birth and vaginal colonization by mycoplasmas in early pregnancy. J Clin Microbiol 44: 51-55.

15. Kasprzykowska U, Elias J, Elias M, Mączyńska B, Sobieszczańska BM (2014) Colonization of the lower urogenital tract with Ureaplasma parvum can cause asymptomatic infection of the upper reproductive system in women: a preliminary study. Arch Gynecol Obstet 289: 1129-1134.

16. Kasper DC, Mechtler TP, Reischer GH, Witt A, Langgartner M, et al. (2010) The bacterial load of Ureaplasma parvum in amniotic fluid is correlated with an increased intrauterine inflammatory response. Diagn Microbiol Infect Dis 67: 117-121.

17. Abele-Horn M, Scholz M, Wolff C, Kolben M (2000) High-density vaginal Ureaplasma urealyticum colonization as a risk factor for chorioamnionitis and preterm delivery. Acta Obstet Gynecol Scand 79: 973-978.

18. Raynes Greenow CH, Roberts CL, Bell JC, Peat B, Gilbert GL, et al. (2011) Antibiotics for ureaplasma in the vagina in pregnancy. Cochrane Database Syst Rev.

19. Donders GG, Van Bulck B, Caudron J, Londers L, Vereecken A, et al. (2000) Relationship of bacterial vaginosis and mycoplasmas to the risk of spontaneous abortion. Am J Obstet Gynecol 183: 431-437.

20. Leli C, Meucci M, Vento S, D'Alò F, Farinelli S, et al. (2013) Microbial and vaginal determinants influencing Mycoplasma hominis and Ureaplasma urealyticum genital colonization in a population of female patients. Infez Med 21: 201-206.

21. Manhart LE (2013) Mycoplasma genitalium: An emergent sexually transmitted disease? Infect Dis Clin North Am 27: 779-792.

22. Manhart LE, Broad JM, Golden MR (2011) Mycoplasma genitalium: Should we treat and how? Clin Infect Dis 53: 129-142.

23. Hitti J, Garcia P, Totten P, Paul K, Astete S, et al. (2010) Correlates of cervical Mycoplasma genitalium and risk of preterm birth among Peruvian women. Sex Transm Dis 37: 81-85.

24. Edwards RK, Ferguson RJ, Reyes L, Brown M, Theriaque DW, et al. (2006) Assessing the relationship between preterm delivery and various microorganisms recovered from the lower genital tract. J Matern Fetal Neonatal Med 19: 357-363.

25. Weinstein SA, Stiles BG (2012) Recent perspectives in the diagnosis and evidence-based treatment of Mycoplasma genitalium. Expert Rev Anti Infect Ther 10: 487-499.

26. Kokkayil P, Dhawan B (2015) Ureaplasma: Current perspectives. Indian J Med Microbiol 33: 205-214.

27. Machado Ldel P, Molinari MA, dos Santos L, de Cordova CM (2014) Performance of four commercial kits for laboratory diagnosis of urogenital mollicute infection. Can J Microbiol 60: 613-617.

28. Shipitsyna E, Savicheva A, Solokovskiy E, Ballard RC, Domeika M, et al. (2010) Guidelines for the laboratory diagnosis of mycoplasma genitalium infections in East European countries. Acta Derm Venereol 90: 461-467.

29. Aguilera-Arreola MG, González-Cardel AM, Tenorio AM, CurielQuesada E, Castro-Escarpulli G (2014) Highly specific and efficient primers for in-house multiplex PCR detection of Chlamydia trachomatis, Neisseria gonorrhoeae, Mycoplasma hominis and Ureaplasma urealyticum. BMC Res Notes 7: 433. 
30. Lillis RA, Nsuami MJ, Myers L, Martin DH (2011) Utility of urine, vaginal, cervical, and rectal specimens for detection of Mycoplasma genitalium in women. J Clin Microbiol 49: 1990-1992.

31. Pónyai K, Mihalik N, Ostorházi E, Farkas B, Párducz L, et al. (2013) Incidence and antibiotic susceptibility of genital mycoplasmas in sexually active individuals in Hungary. Eur J Clin Microbiol Infect Dis 32: 1423-1426.

32. De Francesco MA, Caracciolo S, Bonfanti C, Manca N (2013) Incidence and antibiotic susceptibility of Mycoplasma hominis and Ureaplasma urealyticum isolated in Brescia, Italy, over 7 years. J Infect Chemother 19 : 621-627.

33. Krausse R, Schubert S (2010) In-Vitro activities of tetracyclines, macrolides, fluoroquinolones and clindamycin against Mycoplasma hominis and Ureaplasma ssp. isolated in Germany over 20 years. Clin Microbiol Infect 16: 1649-1655.

34. Jensen JS, Cusini M, Gomberg M, Moi H (2016) European guideline on Mycoplasma genitalium infections. J Eur Acad Dermatol Venereol 30: 1650-1656.

35. Renaudin H, Tully JG, Bebear C (1992) In vitro susceptibilities of Mycoplasma genitalium to antibiotics. Antimicrob Agents Chemother 36: 870-872.
36. Guschin A, Ryzhikh P, Rumyantseva T, Gomberg M, Unemo M (2015) Treatment efficacy, treatment failures and selection of macrolide resistance in patients with high load of Mycoplasma genitalium during treatment of male urethritis with josamycin. BMC Infect Dis 15: 40.

37. Ye G, Jiang Z, Wang M, Huang J, Jin G, et al. (2014) The resistance analysis of Ureaplasma urealyticum and Mycoplasma hominis in female reproductive tract specimens. Cell Biochem Biophys 68: 207-210.

38. Koh E, Kim S, Kim IS, Maeng KY, Lee SA (2009) Antimicrobial Susceptibilities of Ureaplasma urealyticum and Mycoplasma hominis in Pregnant Women. Korean J Clin Microbiol 12: 159-162.

39. Zhanel GG, Dueck M, Hoban DJ, Vercaigne LM, Embil JM, et al. (2001) Review of macrolides and ketolides: focus on respiratory tract infections. Drugs 61: 443-498.

40. Leclercq R (2002) Mechanisms of resistance to macrolides and lincosamides: nature of the resistance elements and their clinical implications. Clin Infect Dis 34: 482-492. 